\title{
Approaches to Improve the Ability of Serving Local Economic and Social Development in Higher Vocational Colleges
}

\author{
Rong-Xiang ZHONG ${ }^{1, a}$, Hong GAN ${ }^{2, b}$, Dan $\mathrm{PAN}^{3, \mathrm{c}}$ \\ ${ }^{1,2,3}$ GuangZhou City Construction College, GuangZhou, China, 510925 \\ ainformationcoffer@163.com, bgh2000@163.com, gxing@163.com
}

Keywords: Higher vocational colleges, Services, Local economic and social development, Path.

\begin{abstract}
In this paper, three aspects on the development of higher vocational colleges, from the requirements of local economic and social development situation, Higher Vocational Colleges Serving Local Economic and social development of Higher Vocational Colleges Construction and expansion, emphatically discusses the vocational colleges how to identify the direction of running schools, from the innovative educational ideas, improve the level of running a school, protrude the characteristics of starting, the ability to continuously improve service the development of local economy and society.
\end{abstract}

\section{Requirements for Higher Vocational Colleges, the Development of Local Economy and Society}

The service for the purpose, to meet the needs of economic and social development of applied talents of high quality and high skilled talents, higher vocational colleges is the foundation of existence, is reflected in Higher Vocational Colleges their own value, but also provides the possibility for the development of Higher Vocational colleges. Since twenty-first Century, China has basically formed in each prefecture level city is at least provided a higher occupation colleges pattern [1]. Indigenous and occupation technical, together, become three of the most important features of Higher Vocational colleges. Higher vocational colleges has thus become the contact with the local economic and social development and the interests of the masses of the people the most direct, the most close educational institutions. Requirements for higher vocational colleges to the development of local economy and society are reflected in four aspects:

One is to provide talent support. Since the reform and opening up, it gradually transformed a large number of emerging industries such as information technology, biological technology, numerical control technology, materials technology production from labor-intensive to technology intensive, from the skilled workers and primary talent demand, into the senior skilled talents demand [2]. Talent cultivation in higher vocational colleges must strengthen pertinence and practicability, for local production, construction, management, service line train going down, stay, need high quality applied talents with high skill.

Two is to provide the technical support. Higher vocational colleges, enterprises and local industry fit most closely, not only to promote the self innovation of science and technology, in the invention, advanced technology, advanced technology and other aspects to provide support for local industries and enterprises, and to strengthen cooperation and exchanges, become the local industry, enterprises or other institutions of scientific research achievement transformation of science and technology "experimental field" and "incubator".

Three is to participate in the new rural construction. Higher vocational colleges play an important function directly for services in rural areas, agriculture and farmers, not only to cultivate a large number of professional counterparts of high skilled talents for the construction of new rural areas, but also to actively participate in the transfer of rural labor force training, realize the transformation of the traditional peasant laborers to single skill skilled.

Four is to promote healthy and harmonious development of local education. Higher vocational education is the education system of our country is important one annulus, but between regions, between industry development is not balanced. Better local vocational colleges, is to promote the 
popularization of higher education need in reality on a higher level, more is needed to promote the coordinated and healthy development of the local education reality.

\section{The Current Situation of Higher Vocational College Serving Local Economic and Social Development}

Higher vocational colleges because of its local, vocational, technical, must be suitable to the local economic and social development, meet the practical requirement in quantity, the quality of personnel training, structure. But at present, most colleges in the actual school, there are many aspects of local economic and social development.

One is the orientation of running a school is not clear. The development of vocational education can not deviate from the local economic construction and social development needs, higher vocational colleges must consider providing talent support and technical support for the local and industry, close to the need to develop local and industry. At present our country higher vocational colleges on how to docking industry and enterprise development to serve the local economic construction target positioning is not very clear. Reflected in the specific direction of the training, tend to be higher education, training of general type and type of talent, not tend to vocational education, training skilled and practical talents.

Two is the thought of running a school is not clear. Higher vocational colleges take the employment as the guidance, must take the school enterprise cooperation and work study combination way, meet the needs of the market. At present, many higher vocational colleges in promoting school enterprise cooperation and work study combined with insufficient attention, lack of funds investment led to a mere formality. Moreover, most colleges in the setting of professional did not seriously consider the market demand, generally set up social hot degree and high running cost is low, quick professional, lead to "the coexistence of talent shortage" and "excess talent" two kind of phenomena.

The three is education level is not high enough. Teachers are the basis to decide the level of Higher Vocational colleges. Higher vocational colleges must have a reasonable structure optimization and rich practical experience of double teacher type. But most of the higher vocational colleges were upgraded from secondary vocational schools, the original teachers can not adapt to the requirements of Vocational Education in the quality and structure. The new teacher most is from the culture of "academic" and "Engineering" type talents of the ordinary institutions of higher education graduates, the relative lack of production practice and technical application ability, classroom teaching is difficult to practice and the combination of production. Although, hire and the introduction of a number of good practice in the enterprise of high skill talents of many higher vocational colleges, it is still a drop in the bucket.

The four features are the lack of explicit. The characteristics of running higher vocational colleges life is. The main characteristics embodied in the "local" and "professional" two aspects, "local" is closely fit the local economic and social development, "professional" is to train personnel of high professional quality, strong practical skills. But at present, most professional vocational institutes tend to be small and complete, small and scattered, personnel training tends to Professor of theoretical knowledge, and local industries and enterprises don't have enough interaction between moral education and skills trainings are not enough.

\section{Ways to Improve the Ability of Serving Local Economic and Social Development in Higher Vocational Colleges}

\section{To Serve the Local Economic and Social Development as a Pointer, Identify the Direction of Running a School}

To correctly understand the fundamental attribute of higher vocational education. Higher vocational colleges in the development of cognition and the specific orientation of running a school, should be fully aware of the higher vocational education is not only an important part of higher 
education system in China, is also a kind of training high quality skilled personnel type of higher education. Compared with the ordinary undergraduate colleges and universities, there are not only different levels, more different types of, not to the construction of research university as the goal, but to develop and undergraduate dislocation. Otherwise, will it inevitably bring about a large surplus of academic talents and a serious shortage of technology talents problem, caused by the imbalance of social structure of talent.

The second is to closely fit the local economic and social development planning. Each area due to the geographic location, natural resources, human resources and so on is different, each local economic development direction, planning goals also have great differences. Higher vocational education development direction and the local economy to adapt to not only reflected in the static state, also reflected in the dynamic. Higher vocational colleges must understand the local characteristics of the economy and the future direction of development, pay close attention to the development of local economic and social planning and long-term development goal, grasp the basic direction of vocational training, make it adapt to the development of the development of Higher Vocational Colleges and local social economy, culture is able to welcome by the local market, enterprises of high professional skills talent.

The third is to accurately grasp the characteristics and focus on local economic and social development. Higher vocational education goal is to highlight the local characteristics, according to the development degree, the stage of development of local economy and industry specific requirements of post occupation groups in different industries to locate, by focusing on the main direction of economic development of local city, county and key industries, grasp of professional and technical personnel required for local for a long time in the industry the location and orientation of the industry, to further clarify the goals and directions of its talent cultivation.

\section{Taking the School Enterprise Cooperation, Combination of Engineering as a Supporting Point, Innovative Educational Ideas}

"School enterprise cooperation, work study combination", is the law, comply with the occupation education in higher vocational colleges development, improve the level of running a concise characteristics, enhance the route one must take cultivating ability and social service ability, but also the common orientation of higher vocational education development in the world. Higher vocational colleges by way of "school enterprise cooperation, work study combination" of the road, and constantly innovative educational ideas, to form their own characteristics, in order to achieve innovation in the reform of the education system, formed its own vitality and competitiveness.

A good plan must from the strategic level. Planning of "school enterprise cooperation and work study combination", the innovation of educational ideas, school should rise to the height of the development strategy considerations. Should hold to from our own reality, starting from the local economic and social development, starting from the need to cultivate professional talents, especially should pay attention to the study is based on industry and development problem. To strengthen the school allocation of resources, so that limited resources play a multiplier, the amplification effect.

Two from the implementation level to accelerate. The enterprise of "school enterprise cooperation and work study combination" lack of enthusiasm, this is a headache for most of the problems in the work of Higher Vocational colleges. This problem, and the lack of effective policy support related, and school own strength is not strong, lack of attractiveness. Higher vocational colleges should be more research to enhance its own attractive problem. The school setting majors and courses should not simply consider the need for their own teaching, more from the "school enterprise cooperation and work study combination" point of view of professional and curriculum, and common development of enterprise and industry needs for industry, industry, enterprise of professional and curriculum, enhance the professional and curriculum attraction. In school training base of school should not only meet the requirements of the school teaching, but also to meet the enterprise need particular industry personnel training, enhance the attractiveness of the hardware and software facilities. The school teaching organization and arrangement of clinical practice should be able to guarantee the needs of teaching, but also can adapt the enterprise production and 
employment needs, to enable students to truly become a post staff of enterprise, to enable students to constantly practice has become an important part of enterprise employment plan, enhance the attraction for students' practice. The school should help the enterprise staff training, development and promotion of technology, take the initiative to provide education and technical service for the enterprise, enhance the attractiveness of the school service.

\section{Take the Talent's Training Mode Innovation as a Driving Force, to Improve the Level of Running Schools}

One is to establish a training model for vocational talents training target. The innovation of the mode of talent cultivation in higher vocational colleges, to do a good job in "three docking" [4], i.e. docking educational concept and enterprise with the docking, the concept of the production environment and teaching environment and the enterprise practice docking, evaluation standards and enterprise standards of quality. In order to achieve the three close, that is close to the market demand of specialty setting, close to the curriculum setting position, close to the employer demand for talent cultivation. To adhere to the four aspects, namely, insist to face a society to open widely the use of social resources and provide services for the society, facing the open teaching process to cultivate students' observation, thinking and problem solving ability, opening to the outside world learning domestic and international advanced technical knowledge, future oriented enterprises, the development of the industry to open ahead of [4].

The second is to establish a high quality of double teacher type. Higher vocational colleges must thoroughly change the traditional "subject standard" curriculum, pays equal attention to with the unity of theory and practice teaching, pay attention to the combination of technical ability and humanity quality and financing. In order to make up for the teachers' practical ability is poor, the practical teachers shortage, vocational colleges should actively take effective measures to promote the school teachers regularly to the enterprise learning and training, strengthen practical ability. At the same time, should actively recruit industry, have rich practical experience of enterprises and social expert or professional and technical personnel as part-time teachers. We will strive to realize the sharing and enterprise human resources, reduce teacher introduction and training of repeated labor and the corresponding cost. We will strive to realize the sharing and enterprise human resources, reduce teacher introduction and training of repeated labor and the corresponding cost. And the enterprise personnel in teachers sharing degree more high, that schools and society, enterprise integration degree is high, the higher the [5] school reputation.

The third is to establish the training base of high efficiency and high quality. At present, the development of China's Higher Vocational Colleges most at the initial stage, less funding, technology is weak, the lack of teachers, poor school conditions, most of them failed to establish a complete and efficient training base system, causing bottlenecks in the cultivation of high skilled talents. Higher vocational colleges should be in the establishment of Campus Training Base at the same time, and actively carry out cooperation in running schools, establish training base. The experience and lessons of foreign vocational education development trend and China's vocational education development shows that the training base construction in higher vocational colleges, to vigorously advocate go school enterprise and University (Institute), school field (farm) to build jointly, build roads, realize the complementary advantages of both sides of resource sharing, mutual benefit and win-win. To build a training base, campus training base is the beneficial supplement, but also conducive to guide students to contact the society, also conduce to the various higher vocational colleges at any time to grasp the change rule of the talent market, the timely adjustment of the direction of personnel training, is the effective form of Local Higher Vocational colleges directly serve the local economy.

\section{Graduates with High Quality Employment as the Goal, Highlight the School Characteristics}

One must have a clear view of higher vocational quality is the quality of employment outlook. Vocational education is the employment education. Vocational education must satisfy the needs of the people must improve the quality of employment, employment quality is not to mention is the vocational education, therefore, the quality concept of higher vocational education is employment 
quality, the quality of employment should also must become an important yardstick to measure the level of [6] in Higher Vocational education. Higher vocational colleges must be based on improving the employment rate of graduates, conscientiously do a good job of students' career planning and guidance, comprehensively enhance the graduates' employment, and strive to improve the quality of college graduates' employment.

The second is to focus on building the local specialty. Higher vocational colleges must adhere to the professional construction as a leader, to integrate the local economic and social development needs, the establishment and adjustment mechanism of the development of professional, closely follow the trend of economic and social development, and constantly develop new professional, the transformation of old major, the optimization of specialty structure. Specialty construction should highlight local, construction of a number of clear positioning, social adaptability, good employment prospects brand specialty, gradually formed to meet the professional chain of local economic and social development needs and professional group. Specialty construction should highlight the professional, follow the law of culture technology applied talents, constructing the curriculum system meet the integrity of knowledge, skills, quality of professional work needs, enhance the graduates' competitiveness in the talent market.

Tak Hing double technical three should strive to achieve the graduates. An employee in the enterprise is successful, the technical ability is a basic requirement, but the key working attitude and character is successful, there is no correct working attitude and professional ethics, their technical ability can not give full play to the enterprise growth, and will bring negative influence. Higher vocational colleges should not only pay attention to the students engaged in a professional knowledge and ability, but also should pay more attention to moral education and humane art quality education, so as to make the graduates of professional quality and practical skills has not only excellent, but also with the humanistic spirit and good professional ethics, to become useful talents Tak Hing double technical.

\section{References}

[1] Ren Junqing. Study on the development strategy of [1] [J]. in Higher Engineering Education of higher occupation education in China, 2012.

[2] Liu Aiping. The economic growth of the labor force "Para supply theory [N]. Hubei daily weekly, (2013).

[3] Dong Dakui, Liu Gang. The German University of Applied Science and technology school running mode and Its Enlightenment of [J]. education development research, (2012).

[4] Wang Yao. To highlight the characteristics, improve the level of Higher Vocational Colleges [J]. Ningxia education, (2012).

[5] Zhou Qun. Team building strategy of Vocational College Teachers [J]. China Vocational and technical education, (2013(14).

[6] Feng Jian. The quality of employment is higher vocational education development of the base [N]. the Chinese people's Political Consultative Conference Report education online magazine, (2014).

[7] Lu Jinzhen; Dewey on the occupation and education thought and Its Enlightenment of [J] for higher vocational education; Yanbian Party School Journal; (2011).

[8] Zhou Jiansong; [J]; some thoughts on cultivating famous teacher in higher vocational colleges; higher education of Jiangsu; (2011).

[9] Liu Zhicheng; Wang Yongmei; Yang Lijun;; the development of higher vocational education and regional economic interaction between the [J] best practices; adult education; (2012). 
[10] Li Min; reform and development on the [J] vocational education; entrepreneurial heaven and earth; (2011).

[11] China's Higher Vocational Education "mode analysis of the obstacles of [J] order training; Vocational Education Forum; (2013).

[12] Sun Cuiyu; a few points on higher vocational education thinking [J]; intelligence; (2011).

[13] Sun Zhigang; on the use of process assessment in consideration of [J] in higher vocational education; science and education to guide (the magazine); (2011).

[14] Zhu Fuli; to explore the practice teaching in Higher Vocational Education [J]; youth; (2013). 